\title{
Analisis terhadap Hadis Dasar Hukum Hawalah Fatwa DSN No : 12/DSN-MUI/IV/2000
}

\author{
Munandar Harits Wicaksono $^{\left.1^{*}\right)}$, Rochmat Budi Santoso ${ }^{2)}$ \\ ${ }^{1}$ Pascasarjana Hukum Ekonomi Syariah, IAIN Surakarta \\ ${ }^{2}$ Institut Agama Islam Negeri Surakarta \\ Email korespondensi: cakmun15@gmail.com
}

\begin{abstract}
Abstrak
Debt has become commonplace to meet the needs of human life. However, because it is only a loan, it must be returned. But sometimes not everyone can do it at the agreed time. Therefore, Islam offers a solution in the form of a hawalah contract. The National Sharia Council then issued a fatwa regarding this matter to strengthen it by mentioning several hadiths as its legal basis. With qualitative methods and literature study, the authors describe the understanding that can be drawn from this hadith. Based on the research results, it was found that there were many differences of opinion in the details of the hawalah contract. Then it was also discovered that one of the hadiths that was used as a reference did not have a degree of shohih and the hadith also did not lead directly to the hawalah contract.
\end{abstract}

Keywords: fatwa, hadis, hawalah

Saran sitasi: Wicaksono, M. H. (2021). Analisis terhadap Hadis Dasar Hukum Hawalah Fatwa DSN No: 12/DSNMUI/IV/2000. Jurnal Ilmiah Ekonomi Islam, 7(02), 605-611. doi: http://dx.doi.org/10.29040/jiei.v7i2.2205

DOI: http://dx.doi.org/10.29040/jiei.v7i2.2205

\section{PENDAHULUAN}

Segala bentuk aktifitas ekonomi dilakukan manusia demi memenuhi kebutuhan hidupnya. Salah satu bentuk dari aktifitas tersebut adalah utangpiutang.

Dalam kamus besar Bahasa Indonesia, utang adalah uang yang dipinjam dari orang lain. Sementara piutang adalah uang yang dipinjamkan. Karena hanya bersifat pinjaman, mengembalikan uang tersebut adalah sebuah kewajiban dengan durasi waktu yang disepakati. Namun pada praktiknya, tidak sedikit orang yang berutang tidak mampu memenuhi kesepakatan yang telah dibuat.

Islam sebagai rahmatan lil alamin, memberikan beberapa solusi terkait permasalahan tersebut. Salah satunya adalah dengan memindahkan utang tersebut kepada orang lain. Pemindahan ini disebut dengan akad hawalah.

Akad ini sejatinya sudah diperkenalkan sejak ratusan tahun yang lalu dan bisa ditelusuri dalam kitab-kitab fikih klasik. Di masa sekarang, kemunculan Dewan Syariah Nasional (DSN) sebagai pelaksana tugas dari Majelis Ulama Indonesia (MUI) dalam menetapkan fatwa seputar ekonomi dan mengawasi penerapannya mempertegas kembali akad tersebut sebagai rujukan baik bagi individu maupun perbankan dan lembaga keuangan syariah (LKS). DSN mengeluarkan dua fatwa berkaitan dengan akad hawalah. Yang pertama adalah fatwa No : 12/DSNMUI/IV/2000, sementara yang kedua adalah fatwa No: 58/DSN-MUI/V/2007.

Perbedaan kedua fatwa ini terletak pada jenis hawalah yang juga dibagi menjadi dua dalam literatur fikih. Fatwa No : 58/DSN-MUI/V/2007 berkaitan dengan hawalah bil ujroh (upah). Fatwa ini berlaku hanya pada hawalah mutlaqoh di mana pihak muhal alaih awalnya tidak ada kaitannya dengan hutangpiutang. Jadi ia hanya menolong muhil dengan suatu imbalan karena sebelumnya tanpa memiliki hutang apapun pada pihak muhal.

Sementara itu, fatwa No : 12/DSN-MUI/IV/2000 berkaitan dengan hawalah muqoyyadah, yaitu pihak muhal alaih memang memiliki hutang pada muhil. Penulis akan memfokuskan penelitiannya pada fatwa ini dikarenakan perlu adanya analisis terhadap hadishadis yang dimaksud sebagai dasar hukum dalam 


\section{Jurnal Ilmiah Ekonomi Islam, 7(02), 2021, 606}

fatwa tersebut. Selain itu artikel ini perlu untuk diangkat karena sebagai bahan referensi yang lebih luas untuk studi lanjutan utamanya berkaitan dengan hawalah di Indonesia. Mengingat hawalah adalah salah satu produk akad yang sampai saat ini digunakan dalam masyarakat muslim khususnya di Indonesia.

Sumber utama dalam penelitan ini adalah fatwa tersebut yang nantinya akan diambil dasar hukum berupa hadis-hadis yang tercantum di dalamnya. Kemudian hadis-hadis tersebut akan ditakhrij untuk dilihat siapa saja yang meriwayat sehingga bisa dilihat derajat kekuatannya apakah shohih,hasan atau Dhoif. Setelah itu, guna menganilisis kandungan hadis-hadis tersebut, peneliti merujuk pada kitab-kitab penjelas hadis seperti Subullussalam, Maalimussunan dan lain sebagainya, sebelum kemudian mengaitkan penjelasan tersebut dengan dengan isi fatwa.

\section{METODE}

Dalam penelitiannya, penulis menggunakan metode pendekatan kualitatif dengan jenis penelitian pustaka (library research) dengan menelaah kitabkitab penjelas hadis, dan jenis penelitian deskriptif berdasarkan tingkat eksplanasinya. Dengan adanya penelitian ini diharapkan menjadi tambahan rujukan dan model baru bagi peneliti lain yang berkeinginan membahas hal ini lebih dalam atau semisalnya.

\section{HASIL DAN PEMBAHASAN}

Hawalah atau hiwalah (dengan harokat fathah pada huruf waw atau dengan harokat kasroh (Ash Shon'ani, Tanpa Tahun)) dalam Bahasa Arab memiliki makna yang sama dengan kata attahwil dan intilaq yang berarti memindahkan sesuatu dari satu tempat ke tempat yang lain. (Syakur, 2010) Dikatakan hawaltu syai' apabila ia telah memindahkan sesuatu dari tempat asalnya.

Sedangkan secara istilah, para pakar Fikih mendefinisikannya dengan definisi yang beragam.

a. Ulama mahdzab Hanafi mendefinisikannya sebagai pemindahan hutang dari tanggungan muhil pada tanggungan muhal alaih.

b. Ulama mahdzab Maliki mendefinisikannya sebagai pertukaran hutang dari tanggungan orang yang berhutang (madin) dengan jumlah yang sama kepada yang lain. Hal tersebut menyebabkan pihak pertama (muhil) terbebas dari tanggungan.

c. Ulama mahdzab Syafii mendefinisikannya sebagai aqad yang menghendaki pemindahan hutang dari tanggungan seseorang pada yang lain. d. Ulama mahdzab Ahmad berpendapat bahwa hawalah adalah perpindahan harta dari tanggungan muhil pada tanggungan muhal alaih.

Secara substansial keempat definisi di atas memang hampir mirip. Namun definisi yang diberikan oleh mahdzab Maliki dianggap lebih tepat. Hal ini dikarenakan ketiga mahdzab yang lain tidak menyebutkan syarat ataupun batasan hawalah dalam definisinya. Sementara ulama mahdzab Maliki menyebutkan syarat hawalah adalah jumlah hutangnya harus sama, serta dampak dari hawalah adalah bebasnya pihak muhil dari tanggungan setelah terjadinya aqad(Syata, 2013). Penyebutan syarat semacam ini penting dalam sebuah definisi agar dapat lebih tegas dalam membatasi cakupan pembahasannya.

Dalam pengertian yang lebih umum, hawalah dapat didefinisikan sebagai bentuk perjanjian yang dilakukan oleh tiga pihak, di mana tanggung jawab pembayaran piutang pihak pertama pada pihak kedua ditanggung oleh pihak ketiga sesuai dengan kesepakatan(T. Abrar ZA, 2017).

Definisi di atas mengindikasikan adanya rukunrukun yang harus terpenuhi dalam hawalah. Rukunrukun tersebut adalah muhil, muhal, muhal alaih, muhal bih dan sighoh.

Muhil adalah orang yang berhutang, muhal adalah orang yang memberi hutang, muhal alaih adalah orang yang nantinya akan membayar utang tersebut(Sabiq, 1995), Sementara muhal alaih adalah hak/hutang yang berpindah antar tanggungan, dan sighoh adalah ijab dan qobul dalam aqad.

Kemudian berkaitan dengan hakikat dari hawalah, terdapat perbedaan pendapat antar ulama. Para ulama mahdzab Hambali menurut riwayat mereka yang shohih berpendapat bahwa hakikat dari hawalah adalah bantuan pada praktek akad itu sendiri tanpa dimasukkan pada jenis akad yang lain. Sementara mahdzab Hanafi, Maliki dan Syafii berpendapat bahwa hakikat hawalah adalah jual beli piutang yang hukum asalnya haram namun kemudian diperbolehkan karena adanya kebutuhan(Syata, 2013).

Berkaitan dengan ini, jumhur fuqoha' memang masih memperbolehkan jual beli piutang dalam beberapa bentuk dengan berbagai rincian hukumnya. Berbeda dengan pendapat Ibnu Hazm Adz-dzohiry yang melarang jual beli jenis ini (piutang) secara mutlak(Hammad, 2001). Qodhi Abu Muhammad berpendapat bahwa hawalah merupakan bentuk jual beli hutang yang dikecualikan keharamannya 


\section{Jurnal Ilmiah Ekonomi Islam, 7(02), 2021, 607}

sebagaimana jual beli 'araya(bin Kholaf bin Sa' ad bin Ayub At Tajibi Al Qurtubhi Al Baji Al Andalusy, Tanpa tahun).

Walau demikian, perbedaan antara para ulama mengenai hakekat hawalah tersebut tidak mempengaruhi hokum kebolehannya dalam syariat Islam.

\section{Dasar hukum Fatwa DSN}

Kebolehan hawalah didasarkan pada nash AlQuran, Hadis Ijma' dan Qiyas. Dalam Nash Al-Quran sendiri, sebenarnya tidak pernah disebutkan hukum hawalah secara rinci, bahkan lafalnya yang merujuk pada akad tersebut tidak ada. Namun hukum kebolehannya dapat ditemukan dalam kandungan ayat-ayat yang bersifat global seperti dalam firman Allah dalam surah Al Maidah ayat 2 :

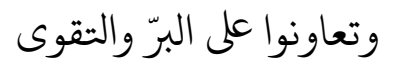

"Dan tolong menolonglah kamu dalam kebaikan."

Sementara hadis -dengan fungsinya sebagai penjelas yang global dan menetapkan sesuatu yang belum ditetapkan dalam Al-Quran, tidak sedikit yang menjelaskan mengenai kebolehan hawalah. Dalam butir pertimbangan fatwa Dewan Syariah Nasional MUI No 12/DSN-MUI/IV/2000, terdapat dua hadis yang kemudian keduanya dijadikan dasar hukum kebolehan aqad hawalah tersebut.

\section{Hadis Pertama}

Dari Abu Hurairah R.A., bahwa Rasulullah S.A.W bersabda :

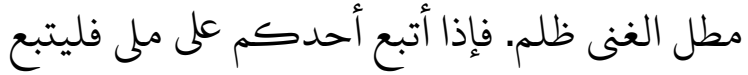
"Menunda-nunda pembayaran utang yang dilakukan oleh seorang yang kaya itu adalah suatu kezaliman. Maka, jika seseorang di antara kamu dialihkan hak penagihan piutangnya (dihawalah) kepada pihak yang mampu, maka terimalah."

Hadis ini diriwayatkan dengan lafal seperti ini oleh Imam Bukhori dalam kitab Sahih pada nomor 2287 dengan jalur periwayatan dari Abdullah bin Yusuf, mengabarkan dari Malik dari Abu Zanad dari A'roj dari Abu Hurairah. Selain itu Imam Bukhori juga menyebutkan pada nomor 2288 dengan jalur periwayatan dari Muhammad bin Yusuf, menyampaikan Sufyan dari ibnu Dzakwan dari A'roj dari Abu Hurairah. Imam Muslim juga meriwayatkan hadis ini lewat Yahya bin yahya dari Malik dari Abu Zanad dari A'roj dari Abu Hurairah(Abu Al Fadl Zainuddin Abdurrahman Al Iroqi, tanpa tahun).
Sementara Imam Thobroni meriwayatkan hadis tersebut dengan huruf waw sebagai ganti huruf $f a$. Sehingga lafal hadis berbunyi :

$$
\text { مطل الغنى ظلم. وإذا أتبع أحدكم على ملى فليتبح : }
$$

"Menunda-nunda pembayaran utang yang dilakukan oleh seorang yang kaya itu adalah suatu kezaliman. Dan jika seseorang di antara kamu dialihkan hak penagihan piutangnya (dihawalah) kepada pihak yang mampu, maka terimalah."

Perbedaan huruf di atas memiliki dampak yang cukup signifikan dalam perbedaan arti dan pemahaman yang timbul. Dari segi arti secara ringkas, Wa memiliki arti "dan" sementara $f a$ memiliki arti "maka".

Dari sisi pemahaman, Imam Rafii menyebutkan apabila menggunakan huruf $f a^{\prime}$, maka kedua kalimat pada hadis tersebut memiliki keterkaitan, sehingga dapat artikan jika menunda pembayaran piutang adalah bentuk kedzaliman, maka hendaklah seorang muhil melakukan akad hawalah. Karena dengan akad hawalah tersebut akan mencegahnya dari penundaan pembayaran hutang yang berujung pada kedzaliman.

Namun apabila memahami hadis yang menggunakan huruf waw, maka bisa diartikan kedua kalimat dalam hadis di atas tidak berhubungan. Sehingga secara garis besar, hadis ini dapat dibagi menjadi dua pembahasan yang berbeda. Yaitu :

Pertama, larangan menunda pembayaran hutang bagi orang kaya saat tiba masa pembayarannya. Landasannya adalah potongan sabda Rasulullah :

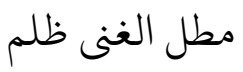

"Menunda-nunda pembayaran utang yang dilakukan oleh seorang yang kaya itu adalah suatu kezaliman ."

Dalam kajian ushul fikih, lafal الغني merupakan kata sifat yang berarti kaya atau mampu. Dengan pengaplikasian mahfum mukholafah, maka dapat dipahami bahwa apabila seseorang masih dalam kondisi miskin dan belum mampu membayar hutangnya maka ia tidak bisa dikatakan telah berbuat dzalim(Hamid Al Khottob, 1932). Demikian juga orang mampu yang sedang tidak diketahui keberadaaannya ( Al Ghony Al Ghoib). Kemudian dari potongan hadis tersebut dapat dipahami juga bahwa orang yang tidak sanggup melunasi, tidak ditagih secara paksa sampai ia mampu(Ash Shon'ani, Tanpa Tahun). 


\section{Jurnal Ilmiah Ekonomi Islam, 7(02), 2021, 608}

Sementara orang mampu akan dianggap telah berbuat Mathlu (مطل) atau menunda apabila orang yang dulu memberinya piutang datang pada waktu penagihan yang sudah disepakati dan bermaksud untuk menangih, namun ia justru menunda pembayaranya tanpa ada udzur yang dapat diterima.

Bila orang yang mampu itu menundanya, maka ia sudah melakukan kedzaliman pada penagihnya. Kedzaliman sendiri adalah perkara yang diharamkan baik besar-kecil, banyak maupun sedikit(Abu Amr Yusuf Al Qurthubi, 2000). Dalam hadis Qudsi, Allah berfirman :

$$
\text { يا عبادى إنى حرمت عليكم الظلم فلا تظالموا }
$$

"Wahai hambaKu, sesungguhnya aku mengharamkan kedzaliman atas diriKu, maka janganlah kalian saling mendzolimi."

Kedua, Hukum kebolehan hawalah. Potongan sabda Nabi Muhammad yang menjadi landasan kebolehan hawalah adalah :

$$
\text { فإذا أتبع أحدكم على ملى فليتبح }
$$

jika seseorang di antara kamu dialihkan hak penagihan piutangnya (dihawalah) kepada pihak yang mampu, maka terimalah."

Potongan hadis ini menunjukkan secara jelas bahwa hawalah merupakan hal yang disyariatkan oleh Islam. Para ulama juga telah bersepakat. Akan tetapi, dalam pembahasan yang lebih detail, ulama kemudian berbeda pendapat akibat keberagaman pemahaman atas potongan hadis itu.

Salah satu permasalahan yang diperdebatkan adalah hukum menerima akad hawalah bagi seorang muhal (orang yang memberi piutang) apabila ia piutangnya dipindahkan pada orang (muhal alaih) yang mampu.

Ulama terbagi menjadi tiga kelompok dalam hal ini. Mahdzab Maliki, Syafii dan Hambali dalam suatu riwayat berpendapat bahwa hukumnya sunah bagi seorang muhal untuk menerimanya. Sebagaimana perkataan Syaikh Abu Muhammad dari mahdzab فليتبع Maliki bahwa perintah "maka terimalah" dalam dalam artian nadzb/sunah(bin Kholaf bin Sa'ad bin Ayub At Tajibi Al Qurtubhi Al Baji Al Andalusy, Tanpa tahun). Sehingga jika ia berkenan menerimanya maka ia akan mendapat pahala karena meringankan beban pihak muhil. Namun bila ia enggan, maka tidak mengapa.

Sementara itu mahdzab Hanafi berpendapat bahwa hukumnya boleh bagi seorang muhal untuk menerima pemindahan tersebut. Dalam artian ia boleh menerima maupun menolaknya. Sedangkan pendapat ketiga, yaitu pendapat mahdzab Hambali yang paling shohih dalam mahdzab mereka menyatakan bahwa seorang muhal wajib hukumnya untuk menerima pemindahan tersebut. Apabila dia enggan, maka dia harus dipaksa(Syata, 2013).

Perbedaan pendapat ini merujuk pada perbedaan dalam penerapan kaidah usul fikih. Sighoh amr/perintah dalam lafal فليتبع dinilai oleh Mahzab Syafii dan Maliki tidak bisa dibawa ke makna hukum asli dari perintah (wajib) dikarenakan ada dalil lain yang menghendaki hukum kesunahan. Dalil lain itu adalah qiyas hawalah terhadap akad serah-terima barang yang mana bukan sebuah kewajiban. Selain itu ada hadis yang diriwayatkan oleh Imam Ahmad yang berbunyi :

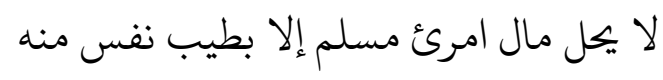

"Tidaklah halal harta seorang muslim (bagi yang lain) kecuali atas kerelaan hatinya."

Hadis ini menunjukan bahwa sesorang tidaklah dipaksa terhadap apapun atas hartanya sampai ia meridhoinya. Sehingga ini menguatkan pendapat فليتب mereka bahwa sighoh amr/perintah dalam lafal mengandung makna hukum sunah, bukan wajib.

Mahdzab Hanafi yang berpendapat bahwa hukumnya mubah berlandas pada pemahaman mereka bahwa sighoh amr/perintah dalam lafal فليتب untuk kemubahan saja. Mereka berdalih secara akal bahwasanya hawalah adalah bagian dari akad jual-beli piutang yang sebenarnya dilarang. Akan tetapi ia dikecualikan dari hukum keharamannya karena kebutuhan mendesakan dalam hidup manusia. Dan sighoh amr/perintah setelah larangan mengindikasikan ibahah/kebolehan sebagaimana kaidah ushuliyah yang berlaku secara umum.

Sedangkan pendapat ketiga, berlandaskan bahwa bahwa sighoh amr/perintah dalam lafal فليتب dibawa ke makna aslinya yaitu wajib karena tidak ada dalil lain yang memalingkan makna hukumnya ke makna ibahah ataupun nadb (boleh dan sunah). Sehingga pihak muhal harus menerima akad aiwalah ini mau tidak mau.

فإذا أتبع أحدكم Kemudian melalui potongan sabda ini juga, Ibnu Hazm berpendapat bahwa hawalah tidak diperkenankan kecuali muhal alaih adalah orang yang mampu. Apabila sang muhal alaih ternyata tidak mampu, maka akadnya menjadi rusak dan hak piutang muhal tetap pada muhil. 


\section{Jurnal Ilmiah Ekonomi Islam, 7(02), 2021, 609}

Pendapat ini dapat dikritisi, karena dalam hadis tersebut tidak ada larangan secara tersurat bahwa akad hawalah tidak sah bila pihak muhal alaih tidak mampu. Yang ada hanyalah perintah untuk menerima akad hawalah bagi muhal alaih dan tidak menjelaskan apapun mengenai kondisi muhal alaih yang tidak mampu. Perkara ini nantinya akan kembali kepada pihak muhal apakah dia akan menyetujui pemindahan tersebut atau tidak.

Kemudian dalam memahami potongan hadis ini juga, ulama berbeda pendapat mengenai disyaratkan atau tidaknya kerelaan pihak-pihak terkait. Jumhur ulama dari mahdzab Maliki, Hambali dan pendapat yang ashoh dari mahdzab Syafii berpendapat bahwa dalam hawalah hanya disyaratkan kerelaan dari muhal dan muhil saja. Sementara itu mahdzab Hanafi, menganggap bahwa kerelaan dari muhal alaih juga merupakan syarat disamping kerelaan muhal dan muhil. Pendapat kedua ini yang diikuti oleh fatwa Dewan Syariah Nasional No : 12/DSN-MUI/IV/2000 yang menetapkan bahwa akad hawalah harus dengan persetujuan muhil, muhal/muhtal, dan muhal alaih sebagaimana tertuang dalam butir fatwa keempat.

Kemudian apabila muhal mensyaratkan pada muhil jika nanti muhal alaih bangkrut atau meninggal, tanggungan piutang akan kembali pada muhil, hal itu diperbolehkan(bin Kholaf bin Sa'ad bin Ayub At Tajibi Al Qurtubhi Al Baji Al Andalusy, Tanpa tahun). Akan tetapi dalam kasus apabila setelah terjadinya akad hawalah, sang muhal alaih mengalami kebangkrutan atau meninggal tanpa adanya kesepakatan sebelumnya, maka ulama berbeda pendapat.

Imam Syafii, Al-Laits, Ahmad, Abu Ubaid dan Abu Ats-tsaur berpendapat bahwa muhal tidak diperkenankan mengembalikan tanggungan piutang pada muhil. Pendapat ini dilandaskan pada pemahaman mereka bahwa pihak muhal alaih sudah semakna dengan menerima barang yang dibeli (qobdhul iwadh).

Semantara itu Sya'bi, Nakho'i, Abu Yusuf dan Muhammad berpendapat bolehnya pengembalian tanggungan piutang pada muhil. Di pihak lain, Abu Hanifah hanya memperbolehkan pengembalian tanggungan piutang pada muhil tersebut apabila muhal alaih mati dalam keadaan bangkrut secara bersamaan(Ibnu Bathol, 2003).

Hukum boleh-tidaknya pengembalian tanggungan piutang ini tidak diputuskan secara tegas dalam fatwa Dewan Syariah Nasional No : 12/DSN-
MUI/IV/2000. Sehingga apabila terjadi kasus semisal di atas, maka penyelesaiannya diputuskan oleh Badan Arbitrasi Syariah bila tidak terjadi kasepakatan melalui musyawarah sebagaimana poin kedua ketetapan fatwa tersebut.

\section{Hadis Kedua}

Adapun hadis kedua yang menjadi landasan fatwa Dewan Syariah Nasional No : 12/DSNMUI/IV/2000 adalah sabda Rasulullah S.A.W :

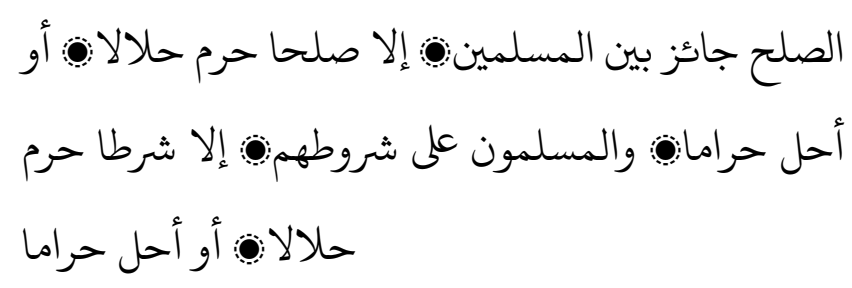

"Perdamaian dapat dilakukan di antara kaum muslimin kecuali perdamaian yang mengharamkan yang halal dan menghalalkan yang haram. Dan kaum muslimin terikat dengan syarat-syarat mereka kecuali syarat yang mengharamkan yang halal atau menghalalkan yang haram."

Dewan Syariah Nasional melandasi fatwa No : 12/DSN-MUI/IV/2000 tentang hawalah dengan riwayat dari imam Tirmidzi dalam kitab Sunannya dengan hanya menyebutkan nama rowi Abdurrahman bin Auf. Jalur riwayat lengkapnya adalah dari Hasan bin Ali Al-Kholal dari Abu Amir Al-Aqody dari Katsir bin Abdullah bin Amr bin Auf Al-Muzany dari ayahnya dari kakeknya(Muhammad At Tirmidzi, 1975).

Sementara imam Baihaqi dalam Sunan Kubronya menyebutkan jalur riwayat yang lain. Yaitu dari Abu Aly Ar-rudzbary, dari Husain bin Hasan bin Ayub Ath-Thusi, dari Abu Yahya bin Abu Musarroh dari Ibnu Zabalah dari Katsir bin Abdullah bin Amr bin Auf Al-Muzany dari ayahnya dari kakeknya(Ahmad Al-Khurosany, 2003).

Imam Tirmidzi mensahihkan derajat hadis ini. Akan tetapi banyak yang mengingkarinya karena Katsir bin Abdullah bin Amr bin Auf Al-Muzany adalah orang yang dhoif berdasarkan kesepakatan ulama jarh wa ta'dil. Kemungkinan, alasan pensahihan imam Tirmidzi adalah karena banyaknya jalan riwayat, karena Abu dawud dan Al Hakim juga meriwayatkan hadis ini dari Katsir bin Zaid dari Walid bin Rabah dari Abu Hurairah(Muhammad AsySyaukani Al Yamani, 1993).

Dari sisi substansi, hadis ini tidak terhubung secara langsung dengan hawalah. Hal ini dapat dilihat 
dari tidak disebutkan permasalahan hawalah dalam kitab-kitab syarh hadis ketika menjelaskan hadis ini. Justru para ulama menjadikan potongan hadis ini sebagai dasar hukum disyariatkannya shuluh/damai. Potongan hadis yang dimaksud adalah :

$$
\begin{aligned}
& \text { الصلح جائز بين المسلمينية إلا صلحا حرم حلالا بي أو }
\end{aligned}
$$

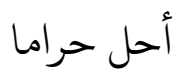

"Perdamaian dapat dilakukan di antara kaum muslimin kecuali perdamaian yang mengharamkan yang halal dan menghalalkan yang haram."

Shuluh dalam bahasa berarti menyelesaikan pertikaian. Sementara Syariat mendefinisikan sebagai akad yang ditetapkan untuk menyelesaikan pertikaian di antara kedua belah pihak.

Ulama membagi shuluh menjadi beberapa jenis. Diantaranya adalah shuluh antara muslim dan kafir, shuluh di antara suami istri, shuluh antara kelompok pembangkang dan kelompok yang lurus, shuluh dalam luka seperti ampunan dengan ganti harta dan shuluh untuk menyelesaikan pertikaian dalam ragam properti dan hak. Jenis terakhir inilah yang dimaksud oleh para ulama Fikih dalam bab shuluh dalam kitab-kitab mereka.

Sementara itu, potongan hadis setelahnya juga tidak terlalu berkaitan dengan hawalah. Potongan hadis tersebut berbunyi :

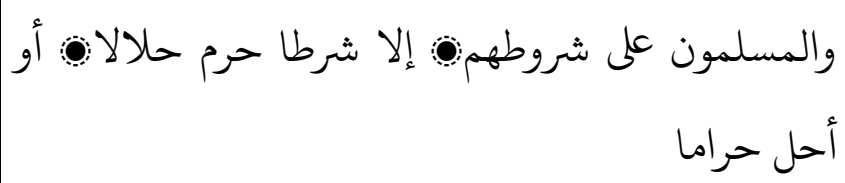

"Kaum muslimin terikat dengan syarat-syarat mereka kecuali syarat yang mengharamkan yang halal atau menghalalkan yang haram."

Yang dimaksud dengan syarat-syarat (شروط) di sini adalah sesuatu yang disyaratkan oleh salah seorang yang berakad kepada orang lain, yang mana dalam persyarat tersebut mengandung maslahah. Hal ini diperbolehkan dan menjadi lazim atau harus dipenuhi apabila pihak lain menyetujuinya dan mengakuinya(Ash Shon'ani, Tanpa Tahun).

Kebolehan dan kelaziman dalam pensyaratan ini bersifat umum. Apapun diperkenankan selama tidak merubah hukum yang sudah ditetapkan oleh Syariat. Contoh pensyaratan yang diperbolehkan adalah apabila seorang pembeli mensyaratkan sifat tertentu terhadap sesuatu yang hendak dibeli semisal kemampuan menulis pada seorang budak.
Dapat dipahami bahwa hadis kedua yang digunakan sebagai landasan fatwa oleh Dewan Syariah Nasional MUI no 12/DSN-MUI/IV/2000 ini tidak berkaitan secara dengan hawalah dalam kitabkitab syuruh/penjelas hadis. Namun, dicantumkannya hadis ini dalam landasan fatwa DSN, berfungsi sebagai penjelas bila dalam proses akad salah satu dari tiga pihak (Muhil, muhal dan muhal alaih) mensyaratkan atau menyepakati sesuatu, maka bila pihak yang terkait dengan persyaratan tersebut menyutujui, tentu wajib baginya untuk memenuhinya selama tidak menghalalkan yang haram maupun sebaliknya.

Sementara itu, apabila merujuk pada refrensi kitab penjelas hadis, akan ditemui hadis-hadis lain yang lebih jelas menunjukkan kebolehannya menanggung hutang orang lain meskipun itu bersifat Hawalah mutlaqah, yaitu pihak muhal alaih adalah orang asing yang awalnya tidak ada kaitannya antar hutang-piutang muhil dan muhal. Sebagaimana hadis yang berbunyi :

وَعَنْ جَابِرِ - رَضِيَ اللَّهُ تَعَالَى عَنْهُ - قَالَ: لاتُوُفَِّ رَجُلُ مِنَّا.

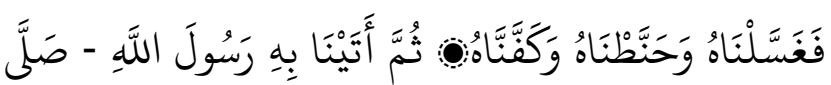

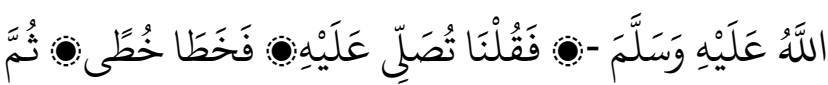

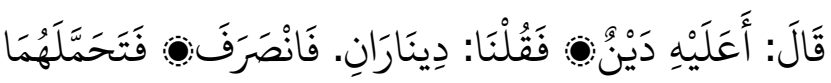

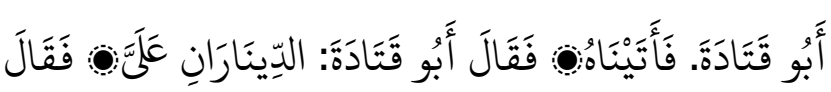

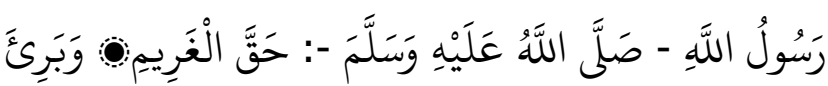

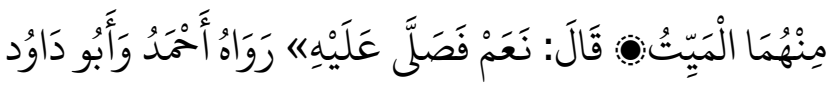

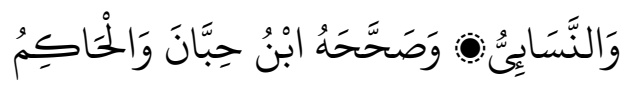

Jabir R.A. berkata : Ada salah seorang di antara kami yang meninggal lalu kami memandikannya dan menutupinya dengan kapas dan mengkafaninya. Kemudian kami mendatangi Rasullullah SAW, dan kami tanyakan: "Apakah baginda akan menyolatkannya? Beliau melangkah beberapa langkah kemudian bertanya "Apakah ia mempunyai hutang?" Kami menjawab "Dua dinar." Lalu beliau kembali. Maka Abu Qotadah menanggung hutang tersebut. Ketika kami mendatanginya, Abu Qotadah berkata : Dua dinar itu menjadi tanggunganku. Lalu Rasulullah SAW bersabda: 


\section{Jurnal Ilmiah Ekonomi Islam, 7(02), 2021, 611}

"Betul-betul engkau tanggung dan mayit itu terbebas darinya." Ia menjawab "ya." Maka beliau menyolatkannya. (riwayat Ahmad, Abu Dawud dan Nasa'I. Hadis shahih menurut Ibnu hibban dan Hakim).

\section{KESIMPULAN}

Hawalah adalah akad perpindahan piutang antar pihak. Walaupun terjadi perbedaan pendapat mengenai hakikat dari hawalah, hal tersebut tidak berpengaruh pada fakta bahwa hawalah adalah akad yang disyariatkan oleh Islam demi mempermudah kehidupan manusia.

Praktik hawalah belakangan ini sering terjadi di Indonesia, karena itu Dewan Syariah Nasioanal berinisiatif mengeluarkan fatwa yang berkaitan dengan akad tersebut. Fatwa yang dimaksud adalah fatwa No : 12/DSN-MUI/IV/2000 dan fatwa No : No : 58/DSN-MUI/V/2007. Fatwa pertama berkaitan dengan hawalah muqoyyadah dan fatwa kedua berkaitan dengan hawalah mutlaqoh.

Sebagai landasan hukum fatwa kebolehan hawalah, DSN menyebutkan dua hadis pada fatwa fatwa No : 12/DSN-MUI/IV/2000. Hadis pertama adalah hadis yang sangat terkenal yang berkaitan dengan hawalah. Meskipun begitu, dalam pemahaman maknanya banyak hal yang kemudian menjadi perdebatan diantara ulama mengenai hukumhukum tertentu.

Sementara hadis kedua, dalam kitab-kitab penjelas hadis, tersebut tidak membahas permasalahan hawalah. Akan tetapi membahas permasalahan Shuluh dan pensyaratan atau kesepakatan sesuatu kepada orang lain. Hadis kedua ini menjadi kunci solusi bila nantinya terjadi permasalahan antara pihakpihak terkait. Permasalahan yang muncul solusinya adalah dikembalikan pada persyaratan yang telah disepakati sebelumnya selama tidak menghalalkan yang haram maupun sebaliknya.

\section{REFERENSI}

Abu Al Fadl Zainuddin Abdurrahman Al Iroqi. (tanpa tahun). Torhu Tastrib fi Syarhi Taqrib. Toba'ah almishriyah Alqodimah.

Abu Amr Yusuf Al Qurthubi, bin A. bin M. bin A. B. bin A. A.-N. (2000). Al-Istidkar. Darul Kutub Ilmiyah.

Ahmad Al-Khurosany, bin H. bin A. bin M. A. (2003). Sunan Al Kubro. Darul Kutub Ilmiyah.

Ash Shon'ani, M. bin I. A. K. (Tanpa Tahun). Subulussalam. PT Diponegoro.

bin Kholaf bin Sa'ad bin Ayub At Tajibi Al Qurtubhi Al Baji Al Andalusy, A. A.-W. S. (Tanpa tahun). Al Muntaqi syarh Muwatha. Darul kutub Islamiyah.

Hamid Al Khottob, bin M. bin I. (1932). Ma'alim Sunan Syarh Sunan Abu Dawud. Almathba'ah Al 'Ilmiyah.

Hammad, N. (2001). Qodhoya fiqhiyah muashoroh fil Maal wal Iqtishod. Darul qolam.

Ibnu Bathol, A. A.-H. A. bin K. bin A. M. (2003). Syarh Shohih Bukhori li Ibni Bathol. Maktabah Ar-Rusyd.

Muhammad Asy-Syaukani Al Yamani, bin A. bin M. bin A. (1993). Nailul Author. Darul Hadis.

Muhammad At Tirmidzi, bin I. bin S. bin M. bin D. (1975). Sunan At-Tirmidzi. Mustofa Albaby Alhalbi.

Sabiq, M. S. (1995). Fiqh Sunah. Darul Fath lil 'Ilam Arobi.

Syakur, A. (2010). Hawalah sebagai Alternatif Pembiayaan Multijasa di Lembaga Keuangan Syariah. Jurnal Muqtashid, 01, 335.

Syata, N. A. M. (2013). Hawalatuddain fil fiqh islami wa tatbiqot muashoroh. Hauliyah Kulliyah Allughoh al Arobiyah Bijarja, 17(1), 832.

T. Abrar ZA. (2017). Hawalah dan Aplikasinya dalam Produk Bai’ Al-Istishna' di Bank Syariah. Jurnal Ekonomi Dan Bisnis Islam, 1(2), 2. 